\title{
UPAYA PEMBINAAN PENDIDIKAN AGAMA ISLAM DAN HUBUNGANNYA DENGAN PRESTASI BELAJAR SISWA DI SMA NEGERI 1 PERBAUNGAN KABUPATEN SERGAI
}

\author{
Ramli Nur
}

Jurusan PPKn Fakultas Ilmu Sosial, Universitas Negeri Medan, Jl. Willem Iskandar Psr. V Medan, Sumatera Utara, 20221, email : ramli_nur2010@yahoo.com

Diterima 16 Mei 2017, disetujui untuk publikasi 15 Juli 2017

\begin{abstract}
ABSTRAK Penelitian ini bertujuan untuk mengetahui usaha-usaha, bentuk pembinaan Pendidikan Agama Islam yang dilakukan guru Agama Islam di SMA Negeri 1 Perbaungan dan hubungannya dengan prestasi belajar siswa dalam Pendidikan Agama Islam di SMA Negeri 1 Perbaungan. Menarik untuk diteliti sebab merupakan sekolah unggulan dibanding SMA lainnya di Kabupaten Sergai, dan mayoritas siswanya beragama Islam, serta termasuk daerah Kabupaten Pemekaran baru. Data penelitian dikumpulkan dengan metode observasi, interview, angket dan library reseach. Analisis data menggunakan metode deskriptif kualitatif dan kuantitatif dimana hasil penelitian disajikan dalam bentuk narasi, tabel/matriks dan rumus hitung. Hasil penelitian menyimpulkan bahwa guru-guru Pendidikan Agama Islam di SMA 1 Negeri Perbaungan sering melakukan kegiatan-kegiatan yang diajarkan
\end{abstract} oleh agama.

\section{Pendahuluan}

Sebagai manusia ciptaan Allah yang paling sempurna, manusia dari makhluk lainnya dengan diberikannya akal pikiran supaya manusia dapat berpikir dan memikirkan akan kebesaran Allah SWT yang telah menciptakannya. Untuk mengetahui dan mempelajari tentang sesuatu hal, manusia harus memiliki agama yang benar, sesuai dengan Al Qur'an surat Ali Imran ayat 19 yang artinya :

Sesungguhnya agama yang diridhoi di sisi Allah adalah agama Islam.

Sebagai agama yang benar di sisi Allah, maka sudah sewajarnya kita yang memiliki akal dan pikiran harus mempelajari agama Islam yang telah kita yakini. Hal ini yang menjadi dasar pemikiran bahwa
Kata Kunci : Pembinaan, Pendidikan Agama Islam, Prestasi Belajar.
Pendidikan Agama Islam harus sudah diterapkan sejak manusia lahir hingga ke liang lahad, dari lingkungan keluarga hingga ke masyarakat, sehingga dapat dikatakan bahwa pendidikan tersebut berlangsung seumur hidup.

Untuk itu maka setiap anak yang telah dilahirkan menjadi tanggung jawab orangtuanya untuk memulai pendidikan agamanya, karena orangtua adalah pembina pribadi yang pertama dalam hidup anaknya. Semenjak dilahirkan, manusia tidak mengetahui apa-apa, yang kemudian diberikan Allah kepada manusia berupa pendengaran, penglihatan dan hati. Sebagaimana yang dituangkan dalam firman Allah surat an-Nahl ayat 78 yang artinya: 
Upaya Pembinaan Pendidikan Agama Islam dan Hubungannya dengan Prestasi Belajar Siswa di SMA Negeri 1 Perbaungan Kabupaten Sergai

Dan Allah mengeluarkan kamu dari perut ibumu dalam keadaan tidak mengetahui sesuatupun, dan Dia memberikan pendengaran, penglihatan dan hati agar kamu bersyukur.

Dilihat dari ayat di atas, maka dengan diberikannya pendengaran, sudah menjadi kewajiban bagi sang ayah untuk mengadzankan di telinga anaknya. Sebagai ajaran pertama tentang Islam, yang merupakan kewajiban bagi setiap orangtua.sabda Nabi Muhammad SAW, yang artinya :

Setiap anak dilahirkan dalam keadaan suci (fitrah), ayah dan ibunyalah kelak menjadikannya Yahudi, Nasrani atau Majusi (penyembah berhala). (HR. Al Bukhori).

Dari hadits di atas, dapat dilihat, bagaimana peranan orangtua di dalam menerapkan pendidikan agama pertama pada anaknya.Setelah beberapa tahun kemudian, sekitar anak berusia sekolah (dimulai \pm 6 tahun), maka tanggungjawab pendidikan agama bukan saja terletak pada orangtua, melainkan juga sudah menjadi tanggung jawab guru Islam yang ada di sekolahnya.Sehingga dengan adanya guru agama Islam tersebut dapat membantu, mengarahkan dan memperbaiki ajaran agama yang telah diterima anak didiknya di rumah.Hal ini dikarenakan bahwa sebelum anak masuk sekolah, si anak telah mendapatkan pendidikan agama Islam di rumah (lingkungan pendidikan keluarga).

Oleh sebab itu, guru agama Islam

harus mampu mengadakan pembinaan agama Islam yang lebih baik dari pada lingkungan keluarga anak di rumah, sehingga dapat meningkatkan generasi penerus bangsa yang berbakti pada agama dan bangsa serta berakhlakul karimah. Sebagaimana yang diharapkan dalam (UU. No. 2 Tahun 2003) tujuan pendidikan Nasional berikut ini : untuk berkembangnya potensi peserta didik agar menjadi manusia yang beriman, dan bertakwa kepada Tuhan Yang Maha Esa, berakhlakul mulia, sehat, berilmu, cakap, kreatif, mandiri dan menjadi warga negara yang demokrasi, serta bertanggung jawab.

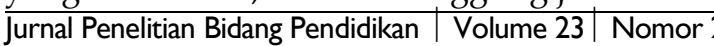

Jadi pendidikan agama Islam adalah bimbingan jasmani-rohani berdasarkan hukum-hukum agama Islam menuju terbentuknya kepribadian utama menurut ukuran-ukuran Islam.

\section{Metode Penelitian}

Penelitian ini dilakakukan di SMA Negeri 1 Perbaungan Kabupaten Sergai. Untuk menghimpun data sebanyakbanyaknya dalam penelitian ini digunakan alat (instrumen) yang sesuai dengan penelitian, yaitu : (a) Observasi yaitu mengadakan pengamatan secara langsung ke lokasi penelitian terhadap obyek yang diteliti. (b) Interview yaitu mengadakan tanya jawab secara langsung dengan kepala sekolah dan guru yang terkait dengan masalah penelitian ini. (c) Angket yaitu mengajukan daftar pertanyaan tertentu yang dilengkapi dengan alternatif jawaban kepada siswa yang menjadi responden (sampel). (d) Library Research (penelitian pustaka) yaitu mengadakan analisa terhadap buku yang berkaitan dengan pembahasan penelitian ini.

Mengumpulkan data diklarifikasi kepada dua jenis penelitian yaitu data kualitatif dan data kuantitatif. Data kualitatif yaitu data yang berbentuk paparan dan uraian kalimat, sedangkan data kuantitatif ialah data yang berbentuk angket dan perhitungan serta dituangkan dalam bentuk tabel.

Untuk memperoleh kesimpulan dari data yang telah diperoleh dan diolah, maka dipakai dua bentuk kesimpulan, yaitu kesimpulan deduktif dan kesimpulan induktif. Kesimpulan deduktif adalah menarik kesimpulan dari umum dilanjutkan kepada masalah yang bersifat khusus, sedangkan kesimpulan induktif yaitu menarik kesimpulan dengan cara masalah yang bersifat khusus kemudian disimpulkan menuju masalah yang bersifat umum.

Dalam mengolah data-data yang peneliti dapatkan, khususnya data angket, 
penulis mempergunakan teknik atau rumusan sebagai berikut:

$\mathrm{p}=\frac{F}{N} x 100$ dengan menggunakan rumus ini, maka peneliti dapat mengetahui perbandingan dan kebenaran adanya hubungan atau tidak antara fasilitas belajar dengan prestasi belajar siswa.

Populasi adalah keseluruhan objek yang diteliti, yaitu seluruh jumlah siswa SMA Negeri 1 Perbaungan yang berjumlah 892 orang.

Sedangkan sampel yaitu sebahagian yang diambil dari populasi (Sudjana, 2002). Kemudian dalam menentukan jumlah sampel, maka dipergunakan rumus sebagai berikut:

$$
n=\frac{N}{N \cdot d^{2}+1}
$$

Dimana : $\mathrm{n}=$ Sampel

$\mathrm{N}=$ Populasi

$\mathrm{d}^{2}=$ Prestasi ditetapkan $10 \%$

atau 0,1 (Rahmat,1985)

Berdasarkan rumus di atas, dapat ditentukan jumlah sampel sebagai berikut:

$$
\begin{gathered}
n=\frac{N}{N \cdot d^{2}+1} \\
n=\frac{892}{892 \cdot 0,1^{2}+1} \\
n=\frac{892}{2,091} \\
n=426,79
\end{gathered}
$$

Maka sampel yang berjumlah 426,79 dibulatkan menjadi 427 orang. Pada penelitian ini sampel ditetapkan menjadi 430 orang.

\section{Hasil Penelitian dan Pembahasan}

Untuk melihat apakah pelajaran Pendidikan Agama Islam di SMA Negeri 1 Perbaungan menyenangkan atau tidak, hal ini dapat dilihat dalam tabel hasil angket berikut ini yang dijawab oleh responden yang ditunjuk sebagi sampel dalam penelitian ini.
Tabel 1. Perasaan Siswa Terhadap Pelajaran Pendidikan Agama Islam

\begin{tabular}{rlrr}
\hline No & Alternatif Jawaban & \multicolumn{1}{c}{ F } & \multicolumn{1}{c}{$\%$} \\
\hline 1 & $\begin{array}{l}\text { a. } \\
\text { b. Kenyenangkan }\end{array}$ & 421 & 98 \\
& $\begin{array}{l}\text { burang } \\
\text { menyenangkan }\end{array}$ & 9 & 2 \\
\hline \multicolumn{2}{c}{ Jumlah } & 430 & $100 \%$ \\
\hline
\end{tabular}

Melalui tabel hasil angket di atas, dapat dilihat bahwasanya dari jumlah responder yang dijadikan sampel sebanyak 430 orang, sebanyak 421 orang atau sebesar 98\% mengatakan bahwa pelajaran Pendidikan Agama Islam di SMA Negeri 1 Perbaungan menyenangkan, dan sebanyak 9 orang atau sebesar 2\% mengatakan bahwa Pendidikan Agama Islam kurang menyenangkan.

Dengan melihat hasil angket tersebut, maka hipotesa yang telah diajukan sebelumnya dapat dinyatakan ditolak, karena tidak mendapatkan dukungan dari jawaban responden/ sampel dalam angket, tetapi berlainan, yaitu ternyata Pendidikan Agama Islam di SMA Negeri 1 Perbaungan menyenangkan sehingga diharapkan dapat membantu meningkatkan prestasi siswa.

Untuk mengetahui hal-hal apa yang menyenangkan di dalam mempelajari Pendidikan Agama Islam di SMA Negeri 1 Perbaungan, dapat dilihat dalam tabel hasil

\begin{tabular}{|c|c|c|c|}
\hline No & Alternatif jawaban & $\mathrm{F}$ & $\%$ \\
\hline \multirow[t]{4}{*}{2} & a. Gurunya & 80 & 18,6 \\
\hline & b. Materi & 270 & 62,8 \\
\hline & c. Metode & 80 & 18,6 \\
\hline & Jumlah & 430 & $100 \%$ \\
\hline
\end{tabular}
angket berikut ini :

Tabel 2. Variabel yang Membuat Siswa Menyukai Pelajaran Pendidikan Agama Islam

Berdasarkan tabel hasil angket di atas, dapat dilihat bahwa dari keseluruhan jumlah reresponden yang dijadikan sampel dalam penelitian ini yaitu yang berjumlah 430 orang, sebanyak 80 atau sebesar 18,6\% menyatakan bahwa yang menyenangkan dalam pelajaran Pendidikan Agama Islam adalah gurunya. Sedangkan sebanyak 270 orang atau sebesar 
$62,8 \%$ mengatakan yang menyenangkan di dalam pelajaran Pendidikan Agama Islam adalah materinya dan sebanyak 80 orang atau sebesar 18,6\% mengatakan yang menyenangkan di dalam mempelajari Pendidikan Agama Islam adalah metode yang dipakai oleh sang guru dalam menarik simpati siswa.

Dengan melihat hasil angket tersebut, maka dapat disimpulkan bahwa bagi siswa SMA Negeri 1 Perbaungan yang menyenangkan dalam mempelajari Pendidikan Agama Islam adalah materinya.Berdasarkan hal tersebut, maka materi Pendidikan Agama Islam adalah merupakan sorotan utama bagi siswasiswinya.

Dengan demikian maka dapat dinyatakan bahwa hipotesa yang telah dicantumkan sebelumnya diterima, karena berbeda dengan hasil angket yang ada.Berdasarkan data,materi Pendidikan Agama Islam lebih disenangi oleh para siswa dalam meningkatkan hasil belajar siswa, dibandingkan dengan metode dan gurunya.

Tabel 3. Guru Memulai Pelajaran Dengan Berdo'a

\begin{tabular}{clrr}
\hline No & Alternatif jawaban & \multicolumn{1}{c}{ F } & \multicolumn{2}{c}{$\%$} \\
\hline 3 & Sering & 345 & 80 \\
& Kadang-kadang & 74 & 17,4 \\
& Tidak pernah & 11 & 2,6 \\
\hline & J u m l a h & 430 & $100 \%$ \\
\hline
\end{tabular}

Untuk mengetahui apakah guru Pendidikan Agama Islam SMA Negeri 1 Perbaungan melakukan pelajaran di awali dengan doa dapat dilihat pada Tabel 3. Berdasarkan tabel 3 hasil angket tersebut di atas, maka dapat diketahui bahwa dari keseluruhan responden yang dijadikan sampel dalam penelitian ini yaitu berjumlah 430 orang, sebanyak 345 orang atau sebesar 80\% mengatakan bahwa guru Pendidikan Agama Islam di SMA Negeri 1 Perbaungan sering melaksanakan do'a dan melakukan hal-hal yang diajarkan oleh agama. Sedangkan sisanya sebanyak 85 orang atau sebesar 20\% mengatakan bahwa guru Pendidikan Agama Islam hanya terkadang saja dan tidak melakukannya.

Dengan melihat hasil angket tersebut, maka dapat disimpulkan bahwa guru Pendidikan Agama Islam di SMA Negeri 1 Perbaungan memang sering melakukan kegiatan-kegiatan yang diajarkan oleh agama. Dari sinilah upaya guru untuk menarik simpati para siswa dalam mempelajari Pendidikan Agama Islam. Dengan adanya kebiasaan-kebiasaan tersebut akan dapat melatih para siswa untuk menjalani kehidupan dengan aturan-aturan yang diterapkan agama Islam. Sehingga guru Pendidikan Agama Islam dapat dinyatakan sebagai pembina Pendidikan Agama Islam.

Peranan guru Pendidikan Agama Islam pada hari-hari besar islammeliputi tertib acarayang akan ditampilkan, melatih serta membina anak-anak duduknya untuk tampil dengan baik, mengajarkan membaca Al Qur'an dan banyak lagi yang lain yang biasa memotivasi siswa agar dapat meningkatkan prestasi mereka khususnya pada bidang studi Pendidikan Agama Islam. Sehingga hal ini dapat menjadi penilaian yang baik bagi masyarakat terutama wali murid SMA Negeri 1 Perbaungan karena kegiatan inilah yang dapat membangkitkan semangat para orang tua murid agar lebih mengedepankan mengimplementasikan pendidikan agama Islam.

Tabel 4. Kegiatan-kegiatan Hari Besar

\begin{tabular}{|c|c|c|c|}
\hline \multicolumn{4}{|c|}{ Islam } \\
\hline No & Alternatif jawaban & $\mathrm{F}$ & $\%$ \\
\hline \multirow[t]{5}{*}{4} & a. Sering & 430 & $100 \%$ \\
\hline & b. Kadang - & - & - \\
\hline & kadang & - & \\
\hline & c. Tidak pernah & & \\
\hline & Jumlah & 430 & $100 \%$ \\
\hline
\end{tabular}

Berdasarkan tabel hasil angket di atas, dapat diketahui bahwa dari keseluruhan responden yang dijadikan sampel dalam penelitian ini, kesemuanya mengatakan bahwa kegiatan-kegiatan dalam memeriahkan 
hari-hari besar bersejarah bagi ummat Islam sering dilaksanakan.

Melihat hasil angket melalui tabel diatas, maka dapat diketahui bahwa guru Pendidikan Agama Islam terhadap siswanya dapat melatih anak didiknya untuk dapat lebih terampil untuk tampil dan maju dalam melakukan kegiatan - kegiatan religius yaitu hari - hari besar bagi ummat Islam. Oleh sebab itu maka hipotesa yang telah diajukan dapat dinyatakan ditolak, karena tidak sesuai dengan jawaban responden melalui angket. Sosok seorang guru merupakan orang tua siswa di lingkungan sekolahnya, oleh sebab itu maka guru harus dapat memenuhi kebutuhan anak didiknya sesuai dengan apa yang dibutuhkannya. Ibarat orang tua yang selalu menginginkan yang terbaik bagi anaknya.Sebagai pengganti orang tua, maka guru harus mampu memberikan kasih sayang kepada anak didiknya, memberi motivasi, memberi peringatan, dan arahan apabila siswanya berbuat kesalahan, serta memberi nasehat-nasehat yang baik dan bermanfaat sehingga siswa tumbuh dengan dibarengi ilmu agama yang cukup.

Aktivitas Guru dalam memberikan bimbingan dan nasehat kepada siswa di SMA Negeri 1 Perbaungan, dapat dilihat pada tabel di bawah ini.

Tabel 5. Aktivitas Guru Dalam Memberikan Bimbingan Dan Nasehat Kepada Siswa

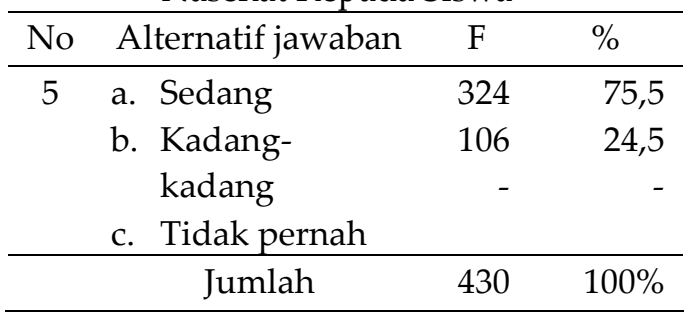

Berdasarkan tabel hasil angket tersebut di atas, dapat dilihat bahwa dari keseluruhan responden yang dijadikan sampel dalam penelitian ini yang berjumlah 430 orang, maka jumlah tersebut terbagi kepada 2 (dua) bagian dalam memilih alternative jawaban angket, yaitu sebanyak 324 orang responden atau sebesar 75,5\% mengatakan bahwa guru Pendidikan Agama Islam di SMA Negeri 1 Perbaungan sering memberikan nasehat kepada siswanya, dan sebanyak 106 orang responden atau sebesar 24,5\% mengatakan bahwa guru Pendidikan Agama Islam hanya kadang-kadang saja memberikan nasehat kepada siswanya.

Dengan mengetahui hasil angket tersebut, maka dapat disimpulkan bahwa memang benar guru Pendidikan Agama Islam di SMA Negeri 1 Perbaungan sering memberikan bimbingan dan nasehat kepada para siswanya.

Namun untuk melihat apakah kegiatan-kegiatan yang berhubungan dengan agama dekat dengan siswa SMA Negeri 1 Perbaungan dapat dilihat pada Tabel 6 berikut ini.

Tabel 6. Kedekatan Siswa Terhadap Kegiatan Religius

\begin{tabular}{|c|c|c|c|}
\hline No & $\begin{array}{c}\text { Alternatif } \\
\text { jawaban }\end{array}$ & $\mathrm{F}$ & $\%$ \\
\hline \multirow[t]{4}{*}{6} & a. Dekat & 327 & 76 \\
\hline & b. Kurang & 100 & 23,3 \\
\hline & $\begin{array}{ll} & \text { Dekat } \\
\text { c. } & \text { Tidak Dekat }\end{array}$ & 3 & 0,7 \\
\hline & Jumlah & 430 & $100 \%$ \\
\hline
\end{tabular}

Berdasarkan tabel hasil angket di atas, dapat dilihat bahwa dari jumlah keseluruhan responden yang dijadikan sampel dalam penelitian ini, sebanyak 327 orang atau sebesar $76 \%$ mengatakan bahwa kehidupan siswa dekat dengan kegiatan religius. Dan sebanyak 100 orang atau sebesar 23,3\% mengakui bahwa kehidupan mereka kurang dekat dengan kegiatan religius. Disamping itu sebanyak 3 orang atau sebesar $0,7 \%$ mengakui bahwa kehidupan mereka dengan kegiatan religius sama sekali tidak dekat.

Melihat hasil angket di atas, dapat disimpulkan bahwa kehidupan kegiatan siswa SMA Negeri 1 Perbaungan dekat dengan agama sehingga hipotesa yang telah dicantumkan sebelumnya dapat dikatakan ditolak. 
Penilaian tentang hasil belajar siswa pada umumnya dilaporkan oleh guru (pihak sekolah) kepada orang tua/wali siswa dalam bentuk rapot. Rapot adalah catatan angkaangka yang menggambarkan nilai/hasil yang telah dicapai, siswa selama mengikuti proses kegiatan belajar dalam jangka waktu 1 (satu) semester ( 6 bulan sekali), melalui buku rapot tersebut dapat diketahui bagaimana prestasi siswa yang menjadi anak didiknya. Nilai-nilai tersebut disusun berdasarkan urutan mata pelajaran yang dipelajari di sekolah, seperti Pancasila, Bahasa Indonesia, Bahasa Inggris, Matematika, Pendidikan Agama Islam dan Lain-lain. Begitu juga yang dilakukan di SMA Negeri 1 Perbaungan yang juga mengajarkan beberapa mata pelajaran dan dinilai melalui evaluasi, dan hasilnya dituangkan dalam sebuah buku laporan yaitu rapot. Untuk mengetahui bagaimana hasil belajar siswa dalam bidang studi Pendidikan Agama Islam di SMA Negeri 1 Perbaungan dapat dilihat pada Tabel 7.

Tabel 7. Nilai Siswa Mata Pelajaran Agama

\begin{tabular}{|c|c|c|c|}
\hline \multicolumn{4}{|c|}{ Islam } \\
\hline No & $\begin{array}{l}\text { Alternatif } \\
\text { jawaban }\end{array}$ & $\mathrm{F}$ & $\%$ \\
\hline \multirow[t]{4}{*}{7} & a. Baik & 363 & 84,5 \\
\hline & b. Kurang Baik & 67 & 15,5 \\
\hline & c. Tidak Baik & - & 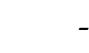 \\
\hline & Jumlah & 430 & $100 \%$ \\
\hline
\end{tabular}

Berdasarkan tabel hasil angket diatas, maka dapat diketahui bahwasanya dari keseluruhan responden yang menjadi sampel dapat penelitian ini yang berjumlah 430 orang, sebanyak 363 orang atau sebesar $84,5 \%$ mengatakan bahwa nilai Pendidikan Agama Islam adalah baik, dan sebanyak 67 orang responden atau sebesar $15,5 \%$ mengatakan kurang baik.

Dengan melihat hasil angket di atas, maka dapat disimpulkan bahwa nilai Pendidikan Agama Islam yang diterima oleh siswa-siswa SMA Negeri 1 Perbaungan dalam keadaan baik, sehingga dengan nilai tersebut sudah barang tentu prestasi siswa juga baik.
Dengan begitu maka dapat dikatakan bahwa hipotesa ditolak, karena tidak mendapatkan dukungan dari jawaban responden melalui angket yang ada.

Hasil belajar tersebut, akan dapat dilihat dan diketahui sekali dalam 6 bulan (semester), bagaimana kondisi prestasi belajar tersebut dapat dilihat, apakah mengalami peningkatan ataukah mengalami penurunan dalam kurun waktu tersebut, dapat diketahui pada tabel berikut:

Tabel 8. Kondisi Nilai Pendidikan Agama Islam

\begin{tabular}{clrr}
\hline No & Alternatif jawaban & \multicolumn{1}{c}{ F } & \multicolumn{1}{c}{$\%$} \\
\hline 8 & a. Meningkat & 373 & 86,8 \\
& b. Kurang & 51 & 11,9 \\
& Meningkat & 6 & 1,3 \\
& c. Tidak Meningkat & & \\
\hline \multicolumn{2}{c}{ Jumlah } & 430 & $100 \%$ \\
\hline
\end{tabular}

Berdasarkan tabel hasil angket di atas, dapat diketahui bahwasanya dari seluruh jumlah responden yang dijadikan sampel dalam penelitian ini, lebih dari setengahnya mengatakan nilai Pendidikan Agama Islam mereka meningkat yaitu, sebanyak 373 orang atau sebesar $86,8 \%$. Sebanyak 51 orang atau sebesar 11,9\% mengatakan bahwa nilai Pendidikan Agama Islam mereka kurang mengalami peningkatan dan sebanyak 6 orang atau sebesar 1,3\% mengatakan bahwa nilai Pendidikan Agama Islam mereka tidak mengalami peningkatan.

Dengan melihat hasil angket tersebut di atas, maka dapat disimpulkan bahwa nilai Pendidikan Agama Islam siswa SMA Negeri 1 Perbaungan mengalami peningkatan dibandingkan dengan semester sebelumnya. Dengan demikian dapat disimpulkan bahwa hipotesa yang telah dicantumkan sebelumnya dapat dinyatakan ditolak.

Selanjutnya untuk mengetahui peranan guru dalam memperhatikan nilai-nilai siswa dalam bidang studi Pendidikan Agama Islam, dapat dilihat pada tabel berikut: 
Tabel 9. Perhatian Guru Terhadap Nilai Siswa

\begin{tabular}{|c|c|c|c|}
\hline No & Alternatif jawaban & $\mathrm{F}$ & $\%$ \\
\hline \multirow[t]{5}{*}{9} & a. Sangat & 430 & 100 \\
\hline & Perhatian & - & - \\
\hline & $\begin{array}{ll}\text { b. } & \text { Kurang } \\
& \text { perhatian }\end{array}$ & - & - \\
\hline & c. Tidak perhatian & & \\
\hline & Jumlah & 430 & $100 \%$ \\
\hline
\end{tabular}

Berdasarkan tabel hasil angket diatas, dapat dilihat bahwasanya dari keseluruhan jumlah responden, yang dijadikan sampel dalam penelitian ini, maka dapat dinyatakan bahwa semuanya yang berjumlah 430 orang responden atau sebesar 100\% mengatakan bahwa guru Pendidikan Agama Islam sangat memperhatikan bagaimana nilai-nilai yang diperoleh mereka.

Untuk mengetahui apakah nilai Pendidikan Agama Islam tersebut dipengaruhi atau tidak oleh kegiatan keagamaan yang dilaksanakan di sekolah SMA Negeri 1 Perbaungan dapat dilihat dalam Tabel 10.

Tabel 10. Pengaruh Kegiatan Keagamaan Terhadap Nilai Siswa

\begin{tabular}{clrr}
\hline No & Alternatif jawaban & \multicolumn{1}{c}{ F } & \multicolumn{1}{c}{$\%$} \\
\hline 10 & a. Mempengaruhi & 323 & 75,2 \\
& b. Kurang & 88 & 20,4 \\
& $\quad$ mempengaruhi & & \\
& c. Tidak & 19 & 4,4 \\
& $\quad$ mempengaruhi & & \\
\hline & Jumlah & 430 & $100 \%$ \\
\hline
\end{tabular}

Berdasarkan tabel hasil angket di atas, dapat dilihat dan diketahui bahwa dari seluruh jumlah responden yang dijadikan sampel penelitian ini, lebih setengahnya yaitu sebanyak 323 orang atau sebesar 75,2\% mengatakan bahwa nilai-nilai mereka dipengaruhi oleh kegiatan keagamaan yang dilaksanakan di sekolah dan diikuti oleh para siswa. Sebanyak 88 orang atau sebesar 20,4\% mengatakan bahwa nilai-nilai mereka kurang dipengaruhi oleh kegiatan keagamaan yang dilaksanakan di sekolah, dan sebahagian kecil lagi yaitu sebanyak 19 orang atau sebesar 4,4\% mengatakan bahwa nilai-nilai mereka tidak dipengaruhi oleh kegiatan keagamaan.

Melihat hasil persentase di atas, maka dapat disimpulkan bahwa nilai-nilai agama yang didapat oleh para siswa SMA Negeri 1 Perbaungan dipengaruhi oleh kegiatan keagamaan yang dilaksanakan di sekolah.

Berdasarkan hasil pembicaraan guru Pendidikan Agama Islam dan Kepala Sekolah dengan penulis sebelumnya, bahwa yang menjadi kendala dalam pembinaan pendidikan agama yang dilakukan dalam Pendidikan Agama Islam dengan upaya meningkatkan prestasi belajarnya adalah kurangnya perhatian orang tua/ wali siswa dalam memberikan pembinaan dan perhatian anaknya dalam hal keagamaan. Dalam menjalin hubungan kerjasama antara orang tua dan guru untuk meningkatkan prestasi belajar siswa, selalu terjadi penghalang dari kedua belah tersebut.Terkadang dari pihak orang tua yang selalu tidak mempunyai waktu berkonsultasi kepada anaknya, dikarenakan kesibukannya, sehingga kebanyakan mereka menyerahkan saja sepenuhnya nasib anaknya kepada guru, sehingga keadaan inilah yang menyebabkan guru merasa kewalahan untuk membimbing sekaligus memberikan perhatian penuh kepada siswa semasa di sekolah.

Disamping itu pula ada kendala yang termasuk dari anak itu sendiri yang tidak menyadari keadaan, bahwa masa depan itu adalah miliknya, sehingga kebiasaankebiasaan belajar yang diterimanya akan bermanfaat di masa yang akan datang.

Ada upaya yang dapat dilakukan adalah menjalin hubungan kerja sama tiga arah antara orang tua, guru, dan siswa. Dari pihak orang tua, mulai menyisihkan waktu untuk memperhatikan anaknya, dan dari pihak guru memberikan keterangan perkembangan pendidikan agama anak kepada orang tua/ walinya, serta memberikan nasehat kepada anak didiknya tentang pentingnya Pendidikan Agama Islam untuk menghadapi kehidupan di masa mendatang. 
Dari pihak guru dan orang tua hendaknya lebih merespon situasi perkembangan pendidikan anaknya, dengan cara melibatkannya dalam setiap peringatan hari-hari besar Islam, baik di lingkungan masyarakat maupun di lingkungan sekolahnya. Sehingga dengan terbiasanya mereka mengikuti kegiatan tersebut tersebut, akan melatih mereka untuk lebih menerapkan pola hidup yang tidak bertentangan dengan ajaran agama.

Berikut ini adalah rekapitulasi hasil angket pada penelitian ini :

Tabel 11. Rekpitulasi Hasil Angket Jawaban Respon

\begin{tabular}{|c|c|c|c|c|}
\hline No & Tabel & $\begin{array}{c}\text { Kode } \\
\text { Jawaban }\end{array}$ & $\mathrm{F}$ & $\%$ \\
\hline \multirow{3}{*}{1} & \multirow{3}{*}{ I } & A & 421 & 98 \\
\hline & & B & 94 & 2 \\
\hline & & C & - & - \\
\hline \multirow{3}{*}{2} & \multirow{3}{*}{ II } & A & 80 & 18,6 \\
\hline & & B & 270 & 62,8 \\
\hline & & C & 80 & 18,6 \\
\hline \multirow{4}{*}{3} & \multirow{4}{*}{ III } & A & 345 & 80 \\
\hline & & B & 74 & 17,4 \\
\hline & & C & 11 & 2,6 \\
\hline & & A & 430 & 100 \\
\hline
\end{tabular}

\begin{tabular}{rrrrr}
4 & IV & B & - & - \\
& & C & - & - \\
\hline \multirow{3}{*}{5} & & A & 324 & 75,5 \\
& V & B & 106 & 24,5 \\
& & C & - & - \\
\hline \multirow{2}{*}{6} & \multirow{2}{*}{ VI } & A & 327 & 76 \\
& & B & 100 & 23,3 \\
& & C & 3 & 0,7 \\
\hline \multirow{2}{*}{7} & \multirow{2}{*}{ VII } & A & 363 & 84,5 \\
& & B & 67 & 15,5 \\
& & C & - & - \\
\hline \multirow{3}{*}{8} & \multirow{2}{*}{ VIII } & A & 373 & 86,8 \\
& & B & 51 & 11,9 \\
& & C & 6 & 1,3 \\
\hline & & A & 430 & 100
\end{tabular}

\begin{tabular}{rrrrr}
9 & IX & B & - & - \\
& & C & - & - \\
\hline \multirow{2}{*}{10} & & A & 323 & 75,2 \\
& & B & 88 & 20,4 \\
& & C & 19 & 4,4
\end{tabular}

Berdasarkan tabel rekapitulasi hasil angket di atas, maka dapat dikatakan bahwa hipotesa penelitian ini ditolak, karena hipotesa tersebut berbeda dengan hasil pengujian hipotesa yang telah dilakukan berdasarkan angket yang telah disebarkan kepada para siswa yang menjadi sampel dalam penelitian ini, yang hasilnya bahwa ternyata pembinaan Pendidikan Agama Islam di SMA Negeri 1 Perbaungan telah dilaksanakan dengan baik sehingga dapat meningkatkan hasil belajar siswa.

Hal ini dapat dilihat perbandingan hasilnya, yaitu sebanyak 9 item dari 10 item yang menyatakan ditolak, sedangkan hanya 1 dari 10 item yang diterima. Dengan menggunakan rumus, maka hasil persentase masing-masing adalah berikut :

$\mathrm{P}=\frac{\mathrm{F}}{\mathrm{N}} \times 100 \%$

Dimana :

$\mathrm{P} \quad=$ Persentase

$\mathrm{F} \quad=$ Frekuensi jawaban angket

$\mathrm{N} \quad=$ Jumlah seluruh angket

Ditolak dengan persentase

$$
\begin{gathered}
\mathrm{P}=\frac{\mathrm{F}}{\mathrm{N}} \times 100 \% \\
=\frac{9}{10} \times 100 \% \\
=90 \%
\end{gathered}
$$

Diterima dengan persentase :

$$
\begin{gathered}
\mathrm{P}=\frac{\mathrm{F}}{\mathrm{N}} \times 100 \% \\
=\frac{1}{10} \times 100 \% \\
=10 \%
\end{gathered}
$$

Dengan demikian, maka hipotesa yang telah penulis kemukakan sebelumnya tidak terbukti kebenarannya atau dinyatakan ditolak, dengan jumlah persentasenya sebesar $90 \%$.

\section{Simpulan dan Saran}

Dari hasil penelitian dan pembahasan dapat disimpulkan bahwa tugas-tugas pokok guru di dalam Pendidikan Agama Islam adalah tugas pensucian, yaitu guru 
hendaknya mengembangkan dan membersihkan jiwa peserta didik agar dapat mendekatkan diri kepada Allah SWT, menjauhkan diri dari keburukan dan menjaganya agar tetap fitrah. (b) Tugas pengajaran, yaitu guru hendaknya menyampaikan berbagai pengetahuan dan pengalaman kepada peserta didik untuk diterjemahkan ke dalam tingkah laku kehidupannya. (2) Pertumbuhan dan perkembangan anak bukanlah merupakan hal yang terjadi dengan sendirinya. Sebagaimana halnya dengan tanaman, untuk mendapatkan pertumbuhan dan perkembangan yang maksimal sempurna diperlukan pemeliharaan dan pembinaan agar mencapai tingkat perkembangan yang maksimal, maka diperlukan didikan/proses mendidik. Dari proses pendidikan inilah diharapkan lahirnya kepribadian yang berintegrasi dalam aspekaspek fisik, psikhis, moral, sosial dan spiritual. (3) Kurangnya pembinaan Pendidikan Agama Islam yang efektif, sehingga tidak dapat meningkatkan prestasi belajar siswa dalam Pendidikan Agama Islam di SMA Netgeri 1 Perbaungan Kabupaten Sergai. (4) Proses pembelajran Pendidikan Agama Islam yang menyenangkan, tentunya desebabkan oleh beberapa hal, baik itu yang menyangkut pribadi guru agamanya. Namun ada pula senangnya siswa mempelajari pelajaran tersebut dikarenakan hal-hal yang lain yang menyangkut dengan pelajaran yang dipelajari. (6) Dengan melihat hasil angket tersebut, maka dapat disimpulkan bahwa guru Pendidikan Agama Islam di SMA Negeri 1 Perbaungan memang sering melakukan kegiatan-kegiatan yang diajarkan oleh agama. (7) Peranan guru Pendidikan Agama Islam tersebut meliputi tertib acara yang akan ditampilkan, melatih serta membina anak-anak didiknya untuk tampil dengan baik, mengajarkan membaca AlQur'an dan lainnya yang bisa memotivasi siswa agar dapat meningkatkan prestasi mereka khususnya pada bidang studi Pendidikan Agama Islam.
Disarankan kepada siswa SMA Negeri 1 Perbaungan agar lebih banyak lagi membaca buku-buku tentang Agama Islam, sehingga semakin luas cakrawala berfikir, banyak bertanya kepada guru, ustadz atau ulama dan tokoh-tokoh yang sukses lainnya di sekitar tempat tinggal. Dan juga kepada pemerintah khususnya kementerian Pendidikan Nasional dan Kementerian Agama, agar melengkapi saranan fasilitas buku-buku Agama, disamping itu melakukan pembinaan dan peningkatkan pengetahuan dan keterampilan guru-guru Agama Islam sehingga lebih profesional dan berkompetensi.

\section{Daftar Pustaka}

Al Qur'anul Karim

Alamath, Muhammad Faiz. 1991. 1100 Hadits Terpilih. Jakarta : Gema Insani Press.

Al-Abrasyi, Muhd.Athiyah. 1974. Dasar-dasar Pokok Pendidikan Islam. Jakarta : Bulan Bintang.

Aly, Hery Noer, Drs. MA. 1999. Ilmu Pendidikan Islam. Jakarta : Logos.

Arikunto, S. 1991, Prosedur Penelitian. Jakarta : Rineka Cipta.

Barnadib, Sutari Imam. 1993. Pengantar Ilmu Pendidikan Sistematis. Yogyakarta : Andi Offset.

Breen, M.P \& Candlin, C.N. 2001. The Essentials of Communicative Curriculum Language Teaching, Innovations in English Language Teaching. London : Routledge.

Champion, James A. Black dan Dean, J. 1999. Metode dan Masalah Penelitian Sosial. Bandung : PT. Rafima Aditama.

Departemen Agama RI. 1979. Al Qur'an dan Terjemahannya. Jakarta : Bumi Restu.

Darajat Zakiah. 1975. Kesehatan Mental, Jakarta : Gunung Agung.

Hamalik, O. 1980. Methode Belajar dan Kesulitan-kesulitan dalam Belajar. Bandung : Tarsito.

Marimba, A.D. 1980. Pengantar Filsafat Pendidikan Islam. Bandung : Al Maarif. 
Upaya Pembinaan Pendidikan Agama Islam dan Hubungannya dengan Prestasi Belajar Siswa di SMA Negeri 1 Perbaungan Kabupaten Sergai

Nasution, S., 1982. Berbagai Pendekatan dalam Proses Belajar Mengajar. Bandung : Bina Aksara.

Narbuko, C. \& Achmadi, A. 2002. Metodologi Penelitian. Jakarta : Bumi Aksara.

Poerwadarminta. WJS. 1976. Kamus Umum Bahasa Indonesia. Jakarta : Balai Pustaka.

Praja, M. Sastra. 1991. Kamus Istilah Pendidikan dan Umum. Surabaya : Usaha Nasional.

Qahar, Mas Mas'ud Khasan Abdul. Kamus Ilmiah Populer. Jakarta : Bintang Pelajar.

Rahmat, Jalaluddin. 1985. Metode Penelitian Komunikasi. Remaja. Bandung : Rosda Karya.

Ramayulis, 2008. Metodologi Pendidikan Agama Islam. Jakarta : Kelam Mulia.

Sudirman, AM. 1984. Interaksi dan Motivasi Belajar Mengajar. Jakarta : Rajawali Press.

Tadjib, 1985. Ilmu Jiwa Pendidikan. Jakarta : Aksara Boleh.

Undang-undang Nomor 2 Tahun 2003. Departemen Pendidikan Nasional, Jakarta..

Utomo, T. dan Riutjer,K. 1982. Peningkatan dan Pengembangan Pendidikan. Bandung : Bina Aksara.

Undang-undang Nomor 2 Tahun 2003. 2003. Departemen Pendidikan Nasional, Jakarta.

Undang-undang Republik Indonesia Nomor 20 tahun 2003 tentang Sistem Pendidikan Nasional. 2003. Jakarta : Depdiknas. 